vailable online at website : http://e-journal.adpgmiindonesia.com/index.php/jmie

JMIE: Journal of Madrasah Ibtidaiyah Education, 2(2), 2018, 155-164

\title{
UPAYA MENINGKATKAN PEMAHAMAN KONSEP SISWA PADA MATA PELAJARAN MATEMATIKA MELALUI MODEL PROBLEM POSING PADA SISWA DI SEKOLAH DASAR
}

\author{
Arrahim $^{1)}$, Amelia Nur Fatimah') \\ Universitas Islam “45” Bekasi \\ Email:Arrahimtasrif89@gmail.com¹), ameyliaa24@gmail.com²)
}

Naskah diterima : 7 September 2018, direvisi : 8 September 2018, disetujui : 15 Oktober 2018

\begin{abstract}
This research is motivated by the lack of understanding the concept of students in teaching math. This is evident from the students have not been able to explain the return of the material provided by the teacher, classify an object of such material in accordance with the properties that exist on the material, providing an example of what has been described, presents a picture that relates to the material, students are still difficulties in explains the necessary condition on the content being taught, to solve problems by using the steps correctly, solving the problem solving has been explained by the teacher. The purpose of this study is to improve students' understanding of concepts through learning model Problem Posing in Class VI SDIHuda AL East Bekasi.

Type of this research is the Classroom Action Research (PTK) and lasts for two cycles. Each cycle consisted of four meetings, with the stages of planning, implementation, observation, and reflection. Subjects in this study were students of class VI SDI-Huda AL East Bekasi with the number of students 23 students consisting of 9 male students and 14 female students. The data were obtained by tess and observation. Data were analyzed by descriptive qualitative and quantitative descriptive. The criteria for this research kerberhasilan is when $80 \%$ of the number of students reaching the KKM is 75 .

From the results obtained by the average value of the ability of understanding the concept of students in the first cycle of 75.28 with a percentage of $60.87 \%$ success. then in the second cycle The mean value of understanding the concept of students' ability to increase to 90.11 and $86.96 \%$ success rate. This shows that there is an increased understanding of the concept of the student after the model of Problem Posing. It can be concluded that the use of the model can be meningkatlkan Problem Posing student conceptual understanding in mathematics students of class VI SDI-Huda AL East Bekasi.
\end{abstract}

Keywords: Understanding the Concept, Posin Problem Learning Model, Elementary School Students

Pengutipan: Arrahim \& Amelia Nur Fatimah. (2018). Upaya Meningkatkan Pemahaman Konsep Siswa pada Mata Pelajaran Matematika Melalui Model Problem Posing pada Siswa di Sekolah Dasar. JMIE: Journal of Madrasah Ibtidaiyah Education, 2(2), 2018, 155.164. jmie.v2i2.69.

Permalink/DOI: http://dx.doi.org/ 10.32934/jmie.v2i2.69 


\section{PENDAHULUAN}

Pada jenjeng sekolah dasar, matematika adalah salah satu mata pelajaran yang harus dipelajari sisiwa. Belajar matematika bagi para siswa merupakan alat untuk memahami atau menyampaikan suatu informasi misalnya melalui Persamaan, tabel, grafik atau, diagram. Dengan belajar matematika siswa akan belajar penalaran secara kritis, kreatif dan aktif.

Menurut Undang-Undang Republik Indonesia Nomor 22 Tahun 2006, matematika merupakan salah satu materi yang wajib diajarkan kepada siswa di sekolah. Hal tersebut dikarenakan matematika sering dimanfaatkan dalam kehidupan sehari-hari yang mencakup seluruh aspek kehidupan mulai dari yang sederhana hingga yang paling kompleks.Oleh karena itu setiap siswa wajib memiliki pengetahuan tentang matematika yang harus dipelajari sejak dini mulai dari tingkat sekolah dasar.

Tujuanpembelajaran Matematika di sekolah dasar Menurut Depdiknas dalam Susanto (2016: 190), adalah (1) Memahami konsep matematika, menjelaskan keterkaitan antar konsep, dan mengaplikasikan konsep atau algoritme, secara luwes, akurat efisien dan tepat dalam pemecahan masalah (2) Menggunakan penalaran pada pola dan sifat, melakukan manipulasi matematika dalam generalisasi, menyusun bukti, atau menjelaskan gagasan dan pernyataan matematika, (3) Memecahkan masalah yang meliputi kemampuan memahami masalah, merancang model matematika, menyelesaikan model, dan menafsirkan solusi yang diperoleh, (4) Mengkomunikasikan gagasan dengan simbol, tabel, diagram, atau media lain untuk menjelaskan keadaan atau masalah, (5) Memiliki sikap menghargai penggunaan matematika dalam kehidupan,yaitu memiliki rasa ingin tahu, perhatian, dan minat dalam mempelajari matematika, serta sikap ulet dan percaya diri dalam pemecahan masalah.

Untuk memenuhi semua tujuan pembelajaran matematika terutama dalam memecahkan masalah, siswa harus memiliki pemahaman yang cukup terhadap suatu konsep. Hadi dan Kasum (2015:2) menyebutkan pemahaman konsep matematika merupakan landasan penting untuk berpikir dalam menyelesaikan permasalahan matematika maupun permasalahan sehari-hari. Dengan pemahaman konsep matematika yang baik, siswa akan mudah mengingat, menggunakan, dan menyusun kembali suatu konsep yang telah dipelajari serta dapat menyelesaikan berbagai variasi soal matematika.

Zulkardi dalam Herawati dkk (2010:71) menyatakan bahwa "mata pelajaran matematika menekankan pada konsep". Artinya dalam mempelajari matematika siswa harus memahami konsep matematika terlebih dahulu agar dapat menyelesaikan soal-soal dan mampu mengaplikasikan pembelajaran tersebut dalam dunia nyata. 
Sejalan dengan hal di atas (Depdiknas, 2013: 2) mengungkapkan bahwa pemahaman konsep merupakan salah satu kecakapan atau kemahiran matematika yang diharapkan dapat tercapai dalam belajar matematika yaitu dengan menunjukan pemahaman konsep matematika yang dipelajarinya, menjelaskan keterkaitan antara konsep dan mengaplikasikan konsep atau algoritma secara luwes, akurat, efisien, dan tepat dalam pemecahan masalah.

Indikator pemahaman konsep menurut Kurikulum 2006 dalam Ali Mutohar (2016: 8) adalah: (1) Menyatakan ulang sebuah konsep, (2) Mengklasifikasikan objekobjek menurut sifat-sifat tertentu (sesuai dengan konsepnya), (3) Memberi contoh dan noncontoh dari konsep, (4) Menyajikan konsep dari bentuk representasi matematis, (5) Mengembangkan syarat perlu atau syarat cukup suatu konsep, (6) Menggunakan, memanfaatkan, dan memilih prosedur atau operasi tertentu, (7) Mengaplikasikan konsep atau algoritma pemecahan masalah.

Berdasarkan pendapat di atas dapat disimpulkan bahwa Pemahaman konsep diartikan sebagai kemampuan untuk menyerap arti dari materi atau bahan yang dipelajari dan mengemukakan kembali dalam bentuk lain berupa ucapan atau tulisan kepada orang lain tersebut benar-benar mengerti apa yang disampaikan. Untuk mengajarkan suatu konsep dalam pembelajaran Matematika, seorang guru mampu mengajarkannya dengan konsep yang nyata dimana siswa mampu mengaitkannya dengan kehidupan dilingkungan sekitar.

Dengan mengacu indikator pemahaman konsep meliputi : (1) Menyatakan ulang konsep (2) Mengklasifikasi berdasarkan konsep (3) Memberikan contoh (4) Penyajian konsep (5) Mengembangkan konsep (6) Menggunakan, memanfaatkan, dan memilih prosedur atau operasi tertentu (7) Mengaplikasikan konsep.

Berdasarkan hasil observasi yang dilakukan di SDI AL-Huda, pemahaman konsep siswa pada pembelajaran Matematika belum berjalan secara optimal.Kenyataannya terlihat saat siswa belum dapat menjelaskan kembali materi yang dipelajari. Begitu juga siswa masih bingung dalam mengelompokkan suatu objek dalam materi tersebut sesuai dengan sifat-sifat yang ada pada materi. Dalam hal lain siswa belum mampumemberikan contoh apa yang sudah dijelaskan. Selanjutnya siswa belum mampu menyajikan gambar yang berkaitan dengan materi. Lalu siswa masih bingung saat menjelaskan syarat perlu pada materi yang sedang diajarkan. Selain itu siswa belum mampu menyelesaikan soal dengan menggunakan langkah-langkah yang benar. Hal lain lagi terlihat siswa belum mampu dalam menyelesaikan soal pemecahan masalah yang sudah dijelaskan.Jadi dapat disimpulkan bahwa pemahaman konsep siswa dikatakan rendah. 
Salah satu model pembelajaran yang dapat meningkatkan pemahaman konsep adalah model Problem Posing. Menurut Shoimin (2014:133) Problem Posing memiliki beberapa pengertian. Pertama, merumuskan soal sederhana atau perumusan ulang soal yang ada dengan beberapa perubahan agar lebih sederhana dan dapat dipahamai dalam memecahkan soal yang rumit. Kedua, perumusan soal yang berkaitan dengan syaratsyarat pada soal yang telah di selesaikan untuk meencari alternatif pemecahan lain. Ketiga, perumusan soal dari informasi atau situasi yang tersedia, baik si lakukan sebalum, ketika, atau setelah melakukan suatu soal.

Inhar (2009:45) mengemukakan model Problem Posing atau pembuatan pertanyaan/soal merupakan pendekatan pembelajaran yang diadaptasikan dengan kemampuan siswa dalam proses pembelajaran untuk membangun kognitif siswa serta dapat memotifasi siswa untuk berfikir kritis dan kreatif. Proses berfikir demikian dengan cara meningkatkan schemata yang dimilikinya untuk dipergunakan dalam merumuskan pertanyaan. Dengan model problem posing siswa dapat merumuskan pengalaman langsung dalam bentuk membuat pertanyaan sendiri.

Jadi dapat disimpulkan bahwa model Problem Posing adalah merupakan model pelajaran yang haruskan siswa menyusun pertanyaan sendiri atau memecah suatu soal menjadi pertanya-pertanyaan yang lebih sederhana

Langkah-langkah Problem Posing sebagai berikut:

1. Guru menjelaskan materi pelajaran kepada siswa

2. Guru memberikan latihan soal secukupnya;

3. Siswa diminta siswa mengajukan 1 atau 2 buah soal yang menantang dan siswa bersangkutan harus mampu menyelesaikan. Tugas ini dapat pula dilakukan secara kelompok

4. Selama kerja kelompok berlangsung guru membimbing kelompok-kelompok yang mengalami kesulitan dalam membuat soal dan menyelesaikannya

5. Guru mengevaluasi hasil belajar tentang materi yang telah dipelajari dengan cara masing-masing kelompok atau sebagian dari masing-masing kelompok mempersentasikan hasil pekerjaannya.

6. Guru memberikan reward

7. Guru memberikan tugas individual.

Pendapat di atas diperkuat oleh hasil penelitian yang dilakukan oleh Haerul Syam yang berjudul "Pendekatan Problem Posing Berlatar Pembelajaran Kooperatif Untuk Meningkatkan Keefektifan Pembelajaran Matematika di kelas V SD Negeri I Sungguminasa Kabupaten Gowa". Dari hasil penelitian ini diperoleh bahwa (1) penerapan langkah-langkah pendekatan problem posing dalam pembelajaran matematika 
dapat membantu siswa memahami materi bangun ruang. Hal ini dapat dilihat pada ratarata ketuntasan hasil belajar siswa secara klasikal pada siklus I yaitu 62,5\% dan pada siklus II yaitu 90\% dimana mengalami peningkatan sebesar 27,5\%. Kemampuan guru dalam mengelola pembelajaran pada siklus I sebesar 2,1 dan pada siklus II sebesar 3,4 juga mengalami peningkatan sebesar 1,3.

Penelitian lain juga dilakukan oleh Wulandari yang berjudul "Meningkatkan Pemahaman Konsep Matematika Siswa SD melalui pembelajaran dengan Pendekatan Problem Posing. Yang menyimpulkan bahwa dengan menggunakan pendekatan pembelajaran problem posing pemahaman konsep matematika siswa kelas IV SD meningkat, dengan menggunakan model pembelajaran langsung (direct instruction) pemahaman konsep matematika siswa kelas IV meningkat, dan peningkatan kemampuan pemahaman konsep matematika siswa yang memperoleh pembelajaran dengan menggunakan pendekatan problem posing lebih baik daripada siswa yang memperoleh pembelajaran dengan menggunakan model pembelajaran langsung.

\section{METODE PENELITIAN}

Pelaksanaan Penelitian Tindakan Kelas ini dilakukan dalam bentuk siklus atau putaran kegiatan. Model Kurt Lewin menjadi acuan pokok atau dasar dari adanya berbagai model penelitian tindakan yang lain, khususnya PTK. Konsep pokok penelitian tindakan Model Kurt Lewin dalam Arikunto (2013: 131) terdiri dari empat komponen, yaitu: 1. Perencanaan (planning), 2. Tindakan (acting), 3.Pengamatan (observing), dan 4.Refleksi (reflecting).Subjek dalam penelitian ini adalah siswa Kelas VI SDI AL-Huda Bekasi Selatan yang berjumlah 23 siswa, terdiri dari 14 siswa perempuan dan 9 siswa laki-laki. Penelitian ini dilaksanakan dalam 2 siklus dengan setiap siklusnya 4 pertemuan.Setiap siklus terdiri dari 4 tahapan, yaitu perencanaan, pelaksanaan, pengamatan, dan refleksi.

Teknik pengumpulan data yang digunakan dalam penelitian ini adalah tes, dan observasi.Indikator keberhasilan dalam penelitian ini dinyatakan berhasil apabila ketuntasan klasikal pemahaman konsep dengan menggunakan model Problem Posing mencapai 80\% siswa dari seluruh jumlah siswa yang mendapatkan nilai minimal $\geq 75$.

\section{HASIL PENELITIAN DAN PEMBAHASAN}

Berdasarkan hal tersebut peneliti melakukan penelitian menggunakan model Problem Posingpada pembelajaran Matematika untuk meningkatkan pemahaman konsep.Materi Matematika yang digunakan dalam melalui Problem Posingialah Menggunakan sifat-sifat operasi hitung termasuk operasi campuran, FPB dan 
KPK.Tindakan dalam penelitian ini menggunakan 2 siklus.Pada setiap siklusnya dilakukan 4 kali pertemuan.Tindakan siklus I diharapkan dapat meningkatkan pemahaman konsep siswa.Tindakan siklus II dilakukan berdasarkan hasil dari siklus I yang belum sesuai dengan harapan peneliti.

Hasil penelitian pada siklus I terdapat peningkatan dalam proses pembelajaran dengan menggunakan Problem Posingdibandingkan pada saat peneliti melakukan observasi seperti sebagian siswa lebih aktif dalam pembelajaran dan diskusi dan siswa juga bersemangat sehingga siswa tidak mengobrol dengan temannya. Meskipun terdapat peningkatan, namun hasil siklus I belum mencapai indikator keberhasilan yang ditetapkan yaitu 80\% dengan nilai KKM sebesar 75, maka perlu dilakukan siklus II.

Hasil penelitian dan perolehan nilai evaluasi pada siklus I dan II menunjukkan terdapat peningkatan pemahaman konsep Matematika melalui Problem Posing dibandingkan sebelum penelitian atau saat dilaksanakan observasi. Secara keseluruhan siswa telah dapatmenguasai pemahaman konsep pada semua indikator pemahaman konsep Matematika yang menggunakan model Problem Posing, dimana sebanyak 20 siswa dari 23 siswa atau dengan persentase klasikal 80\% sudah mencapai kriteria keberhasilan pemahaman konsep sangat baik. Adapun perbandingan nilai pemahaman konsep Matematika setiap siklus dapat dilihat pada tabel berikut :

\begin{tabular}{lcc}
\hline \multicolumn{1}{c}{ Keterangan } & Siklus I & Siklus II \\
\hline Jumlah & 1731 & 2073 \\
Nilai Rata-Rata Kelas & 75.29 & 90.11 \\
Nilai Tertinggi & 94.29 & 100 \\
Nilai Terendah & 42.86 & 67.50 \\
KKM Yang Ditentukan & 75 & 75 \\
Jumlah siswa yang mencapai KKM & 14 & 20 \\
\hline Persentase Keberhasilan & $60.87 \%$ & $86.96 \%$ \\
\hline
\end{tabular}




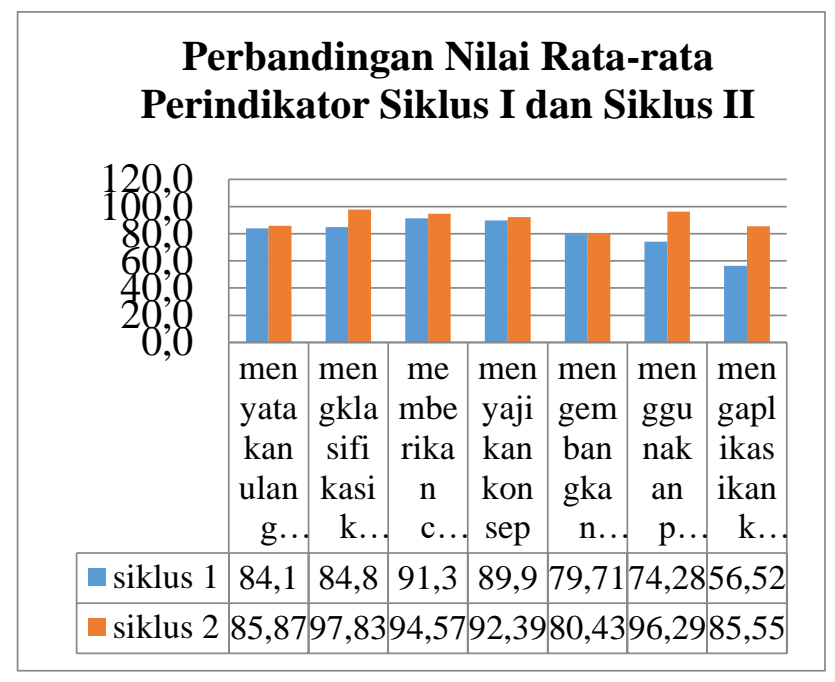

Dari grafik yang telah disajikan di atas, dapat disimpulkan bahwa terjadi peningkatan di setiap siklusnya.Persentase ketuntasan klasikal siswa pada siklus I sebesar $60.87 \%$ dengan jumlah siswa sebanyak 14 siswa namun belum mencapai persentase kriteria keberhasilan minimal 80\%. Pada tindakan siklus II ketuntasan belajar klasikal siswa meningkat sebesar $86.96 \%$ dengan jumlah siswa sebanyak 20 siswa yang telah tuntas sesuai dengan kriteria keberhasilan pemahaman konsep.

Dari hasil tes diperoleh nilai rata-rata kelas mengalami peningkatan dari sebelumnya siklus I sebesar 75.29 dan siklus II menjadi 90.11.Selanjutnya dilihat dari hasil persentase ketuntasan klasikal.Dengan dilakukannya perbaikan atas kekurangan pada siklus I, maka pelaksanaan pembelajaran pada siklus II mampu meningkat dengan baik. Peningkatan ini terjadi karena dalam proses pembelajaran dengan menggunakan Model Problem Posing siswa lebih aktif dalam pembelajaran dan dalam diskusi, siswa bersemangat sehingga siswa tidak lagi mengobrol dengan temannya dan lebih memperhatikan penjelasan guru.

Berdasarkan penjelasan di atas dapat dibuktikan bahwa penggunaan Model Problem Posing dapat meningkatkan kemampuan pemahaman konsep matematika, Peningkatan ini dihentikan karena sudah mencapai kriteria keberhasilan yang telah ditetapkan sebesar 80\%. Hal ini sejalan dengan pendapat Wulandari (2012 :3) Problem Posing, siswa dibimbing untuk merumuskan atau mengajukan masalah atau pertanyaan berdasarkan situasi yang diberikan oleh guru. Dalam merumuskan suatu masalah, siswa harus berpikir dan bernalar, menciptakan dan mengkomunikasikan ide-ide matematis, bekerja sama dan beragumen dalam merumuskan dan menyelesaikan soal dengan temannya, menggunakan informasi yang tersedia untuk menyelesaikan masalah serta 
memikirkan cara yang paling tepat dan masuk akal untuk menyelesaikan masalah yang telah dirumuskan.

Penerapan Model Problem Posing pada mata pelajaran Matematika secara umum dapat meningkatkan pemahaman konsep siswa di kelas VI SDI AL-Huda Bekasi. Peningkatan pemahaman konsep tersebut dapat dilihat dari peningkatan-peningkatan berikut:

1. Hasil penelitian pada siklus I sebanyak 14 siswa dari 23 siswa mencapai KKM $\geq 75$ dengan nilai rata-rata 75.39 , sehingga persentase ketuntasan klasikal sebesar $60.87 \%$.

2. Hasil observasi pada siklus II sebanyak 20 siswa dari 23 siswa mencapai $K K M \geq 75$ dengan nilai rata-rata 90.11 sehingga persentase ketuntasan klasikal sebesar $86.96 \%$.

3. Hasil penelitian pada siklus I dan siklus II mengalami peningkatan sebesar $26 \%$ hal ini menjadi peningkatan yang signifikan.

4. Hasil penelitian siklus II sebesar $86.96 \%$ sudah melebihi persentase ketuntasan yang ditetapkan yaitu $80 \%$ dari jumlah 23 siswa.

\section{KESIMPULAN}

Berdasarkan hasil penelitian dan pembahasan dapat disimpulkan bahwa kegiatan pembelajaran Matematika dengan menggunakan Model Problem Posing dapat meningkatkan pemahaman konsep siswa di kelas VI SDI AL-Huda BekasiTimur. Hal ini ditunjukkan setelah diterapkan Model Problem Posing diperoleh hasil yaitu terlihat adanya peningkatan nilai rata-rata pada siklus I sebesar 75.39 menjadi 90.11 pada siklus II dengan persentase pada siklus I siswa yang mendapat nilai 75 atau lebih sebesar 60.87\% menjadi 86.96\% pada siklus II.

Sedangkan hasil perolehan skor indikator tes pemahaman konsep Matematika juga mengalami peningkatan. Pada siklus I diperoleh rata-rata indikator yaitu: mampu menyatakan ulang sebuah konsep sebesar 84.11 mengalami peningkatan pada siklus II menjadi 85.87, mampu mengklasifikasikan objek-objek menurut sifat-sifat tertentu (sesuai dengan konsepnya) sebesar 91,3 menjadi 94,57 pada siklus II, mampu memberi contoh dan non-contoh dari konsep sebesar 84.8 menjadi 97.83 pada siklus II, mampu menyajikan konsep dalam berbagai bentuk representasi matematis sebesar 89.99 menjadi 92.39 pada siklus II, mampu mengembangkan syarat perlu atau syarat cukup suatu konsep sebesar 79.71 menjadi 80.43 pada siklus II, mampu menggunakan, memanfaatkan, dan memilih prosedur atau operasi tertentu sebesar 74.28 menjadi 96.29 
pada siklus II, serta mampu mengaplikasikan konsep atau algoritma pemecahan masalah sebesar 56.52 menjadi 85.55pada siklus II. Terdapat adanya peningkatan indikator pada siklus I ke siklus II. Dengan demikian siklus dihentikan karena hasil penelitian terdapat peningkatan dan mencapai target yang diinginkan.

\section{DAFTAR PUSTAKA}

Arikunto, Suharsimi. 2013. Penelitian Tindakan Kelas. Jakarta : Bumi Aksara

Hadi dan Kasum. 2015. Pemahaman Konsep Matematika Siswa melalui Peneraoan Model Pembelajaran Kooperatif type Berpasangan (Pair Check). Edu-Mat, Jurnal Pendidikan

Matematika Vol. 3, No. 1 Tahun 2015. Universitas Lambung Mangkurat.

Haerul Syam. 2008. A Problem Posing Approach That Have Cooperative

Instructional Backeground to Increase Mathematics Instructional

Effectiveness. Disertasi dan Tesis Program Pascasarjana UM. (Online)

Tersedia: http://karya-ilmiah.um.ac.id/index.php/disertasi/article/view/863 (diakses 14 Maret 2018)

Herawati, Dkk. 2010. Pengarub Pembelajaran Problem Posing Terhadap Kemampuan Pemahaman Konsep Matematika Siswa Kelas XI IPA SMAN 6 Palembang. Skripsi Tidak Dipublikasikan.

Inhar. 2009. Meningkatkan Hasil Belajar Siswa Kelas VI Melalui Pemelajaran Kooperatif Model

Problem Posing Pada Mata Pelajaran IPS di SDN I Dadakitan :jurnal Kreatif Tadulako

Online Vol. 4 No. 11issn 2354-614x

Mutohar, Ali. 2016. Analisis Kemampuan Pemahaman Konsep. Purwokerto: UMP

Rusman. 2012. Model-Model Pembelajaran Mengembangkan Profesionalitas Guru Edisi Kedua.

Jakarta: PT. Rajagrafindo Persada

Shoimin, Aris. 2014. 68 Model Pembelajaran Inovatif dalam Kurikulum 2013. Yogyakarta: ArRuzz Media

Susanto, Ahmad. 2016. Teori Belajar Dan Pembelajaran Di Sekolah Dasar. Jakarta: Prenadamedia Group

Wulandari, Dwi Putri. 2015. Meningkatkan Pemahaman Konsep Matematika Siswa SD melalui pembelajaran dengan Pendekatan Problem Posing. EduHumaniora: Jurnal Pendidikan Dasar, Vol. 7 No. 2. Cibiru: Universitas Pendidikan Indonesia.

\section{Peraturan Perundang-undangan}

Undang-undang RI Nomor 20 Tahun 2003 TentangSistem Pendidikan Nasional 
Arrahim, dkk

Peraturan Pemerintah Pendidikan Nasional Tahun 2006 tentang Kurikulum SD/MI Memuat 8 Mata Pelajaran Inti

Peraturan Pemerintahan Pendidikan Nasional Nomor 22 Tahun 2006 Tentang Tujuan Pembelajaran Matematika 